\title{
Isolation and Characterization of a Virulent Bacteriophage AB1 of Acinetobacter baumannii
}

\author{
Hongjiang Yang*1, Li Liang ${ }^{1}$ Shuxiang Lin² and Shiru Jia'
}

\begin{abstract}
Background: Acinetobacter baumannii is an emerging nosocomial pathogen worldwide with increasing prevalence of multi-drug and pan-drug resistance. A. baumannii exists widely in natural environment, especially in health care settings, and has been shown difficult to be eradicated. Bacteriophages are often considered alternative agent for controlling bacterial infection and contamination. In this study, we described the isolation and characterization of one virulent bacteriophage $A B 1$ capable of specifically infecting A. baumannii.

Results: A virulent bacteriophage AB1, specific for infecting a clinical strain A. baumannii KD311, was first isolated from marine sediment sample. Restriction analysis indicated that phage AB1 was a dsDNA virus with an approximate genome size of $45.2 \mathrm{~kb}$ to $46.9 \mathrm{~kb}$. Transmission electron microscopy showed that phage AB1 had an icosahedral head with a non-contractile tail and collar or whisker structures, and might be tentatively classified as a member of the Siphoviridae family. Proteomic pattern of phage AB1, generated by SDS-PAGE using purified phage particles, revealed five major bands and six minor bands with molecular weight ranging from 14 to 80 kilo-dalton. Also determined was the adsorption rate of phage $\mathrm{AB} 1$ to the host bacterium, which was significantly enhanced by addition of $10 \mathrm{mM} \mathrm{CaCl}_{2}$. In a single step growth test, phage AB1 was shown having a latent period of 18 minutes and a burst size of 409 . Moreover, $\mathrm{pH}$ and thermal stability of phage AB1 were also investigated. At the optimal pH 6.0, 73.2\% of phages survived after 60 min incubation at $50^{\circ} \mathrm{C}$. When phage $A B 1$ was used to infect four additional clinical isolates of $A$. baumannii, one clinical isolate of Stenotrophomonas maltophilia, and Pseudomonas aeruginosa lab strains PAK and PAO1, none of the tested strains was found susceptible, indicating a relatively narrow host range for phage AB1.
\end{abstract}

Conclusion: Phage AB1 was capable of eliciting efficient lysis of A. baumannii, revealing its potential as a non-toxic sanitizer for controlling A. baumannii infection and contamination in both hospital and other public environments.

\section{Background}

Acinetobacter baumannii is a nonfermentative, nonmotile, catalase-positive, gram-negative bacterium found in soil, water, sewage, and many health care environments. A. baumannii is also a commensal microbe existing on human skin and mucous membrane, capable of opportunistic infections, especially in immunocompromised individuals, including pneumonia, meningitis, septicaemia, and urinary tract infection [1,2]. Since its first discovery, A. baumannii has become resistant to many common antibiotics due to both intrinsic mechanisms and its capability to acquire drug resistance determinants. The increasing prevalence of multi-drug and pan-

* Correspondence: hongjiangyang@tust.edu.cn

1 Key Laboratory of Industrial Microbiology, Ministry of Education, PO Box 08, Tianjin University of Science \& Technology, TEDA, Tianjin 300457, PR China

Full list of author information is available at the end of the article drug resistant $A$. baumannii strains found in clinics has rendered it one of the few important nosocomial pathogens, only next to Pseudomonas aeruginosa among nonfermentative gram-negative bacteria [3,4]. A. baumannii is resistant to dehydration, UV radiation, common chemical sanitizers, and detergents, making it extremely difficult to eradicate A. baumannii contaminations from hospital settings, especially catheter-related devices used in intensive care units (ICU). In fact, regular antimicrobial agents only inhibit its growth. Currently, there are no procedures available for removing $A$. baumannii in hospital environments, greatly increasing the risk of hospitalized patients, especially patients in ICU, to the infection by antibiotic-resistant $A$. baumannii $[5,6]$.

Recently, there have been renewed interests in the researches and applications of bacteriophages as antibacterial agent, partly due to their specificity in targeting and 
lysing host bacteria [7-9]. Discovered over one hundred years ago, bacteriophages have been successfully used in the treatments of various infectious diseases. As an alternative to antibiotic therapy, bacteriophage therapy is potentially a powerful approach for the treatment of bacterial infection, especially when antibiotic resistance is increasingly becoming a serious challenge facing the medical community [10,11]. Recently, bacteriophage preparations have been approved by the Food and Drug Administration of USA as a food additive in ready-to-eat products to prevent foodborne bacterial diseases [12]. Animal tests of phage therapy are being conducted for treatments of various bacteria infections, and many lytic phages have been isolated and tested for such applications [13].

Phages specific to Acinetobacter genus were isolated and subsequently used in phage-typing of Acinetobacter spp. isolates [14,15]. Using an animal model, Soothill examined phage efficacy against infections caused by $A$. baumannii. Specifically, tested mice survived the otherwise lethal challenge of 5 LD50 $\left(1 \times 10^{8}\right)$ cells of a virulent A. baumannii strain, when protected by as few as $10^{2} \mathrm{PFU}$ of one lytic Acinetobacter phage [16,17]. However, to our best knowledge, no detailed characterizations on any lytic A. baumannii phages have been reported $[18,19]$. In this paper, clinical isolates of $A$. baumannii were collected and used as indicator hosts for screening phages in marine sediment sample. Virulent phage AB1 was isolated and characterized. The results showed phage AB1 as a double-stranded DNA bacterial virus capable of efficiently lysing A. baumannii KD311.

\section{Results}

\section{Identification of A. baumannii clinical strains}

Before starting phage screening, clinically isolated Acinetobacter spp. strains were first confirmed the identity of the $A$. baumannii by using sequence information derived from their 16S rRNA gene. As described in Material and Methods, DNA fragment containing 16S rRNA gene from each clinical isolate was PCR-amplified and sequenced. The resulted sequences were deposited to GenBank and aligned to search for the most similar sequences. Five collected clinical strains (KD311, KD312, KD331, KD332, and KD334) were validated to be A. baumannii and KD335 was Stenotrophomonas maltophilia, one pathogen often isolated accompanying with $A$. baumannii infections.

\section{Bacteriophage isolation}

Five A. baumannii clinical isolates were used as indicator strains for virulent bacteriophages screening from marine sediment samples. After enrichment, phage-containing samples were plated onto semi-solid agar plates with the indicator strain forming a bacterial lawn, and plaques were allowed to form by incubating at $35^{\circ} \mathrm{C}$ for 4 hours. Clear plaques were obtained from these samples only when strain KD311 served as the indicator, with plaques forming at size of about 1-2 $\mathrm{mm}$ in diameter. The phage isolate (named AB1) was selected for further study.

\section{Restriction fragment analysis of genomic DNA}

Phage AB1 was amplified and its genomic DNA extracted as described. Purified genomic DNA was digested with several restriction endonucleases or their combiantions, including ApaI, BamHI, BglII, EcoRI, EcoRV, HindIII, KpnI, NcoI, PstI, PvuII, SalI, SphI, XbaI, BglII/XbaI, $E c o$ RI/BglII, and EcoRI/XbaI, and subsequently subjected to electrophoretic analyses. As shown in Fig. 1, out of the tested enzymes, the enzyme combinations generated clear DNA patterns. Based on the digestion profiles of $B g l \mathrm{II} / \mathrm{Xba \textrm {I }}$,EcoRI/BglII , and EcoRI/XbaI, the genome size was determined to be approximately at the range of 45.2 $\mathrm{kb}$ to $46.9 \mathrm{~kb}$. The restriction analyses also indicated that phage AB1 was a dsDNA virus. Determination of the phage genome sequence is also underway.

\section{Morphology study by transmission electron microscopy}

Phage AB1 solution was filtrated with amicon-100 filter to remove soluble macromolecules up to $100 \mathrm{KD}$ in size. After washing three times with $0.1 \mathrm{M}$ ammonium acetate solution, the retained phage solution was used directly

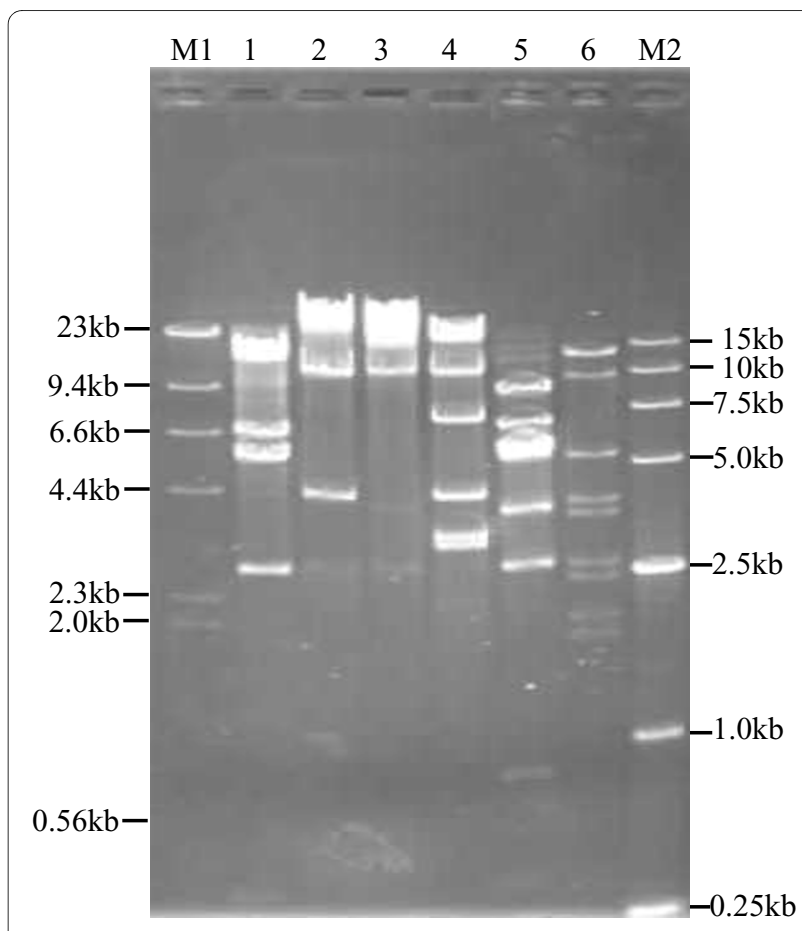

Figure 1 Restriction fragments analysis of phage genomic DNA Phage genomic DNA was digested with EcoRI (lane1), Xbal (lane 2), Bg/ll (lane 3), Bg/ll/Xbal (lane 4), EcoRl/Bglll (lane 5), and EcoRl/Xbal (lane 6), respectively. M1: molecular standard 1; M2: molecular standard 2 
for negative staining. Images of phage AB1 were developed using transmission electron microscope (Fig. 2). The results showed that phage AB1 had an icosahedral head, about $50 \mathrm{~nm}$ in diameter, a $80 \mathrm{~nm}$ long non-contractile tail, and collar or whisker structures, thus morphologically similar to phages belonging to Siphoviridae family.

\section{Proteomic analysis of phage structural proteins}

Purified phage particles were subjected to SDS-PAGE and proteomic patterns were obtained after Coomassie Blue G-250 staining and destaining (Fig. 3). Totally, five major protein bands and six minor protein bands were observed on the gel, with molecular weights ranging from 14 to 80 kilo-dalton.

\section{Determination of the multiplicity of infection (MOI)}

A. baumannii culture of exponential growth phase was aliquot into vials with equal number of bacterial cells $\left(10^{8}\right.$ $c f u)$, which were infected with different amount of phage $\mathrm{AB} 1$ as designed, then plated after 4 hours of incubation. The group with a MOI of $10^{-4}$ gave the highest production of phage progeny $\left(4 \times 10^{10} \mathrm{PFU} / \mathrm{ml}\right)$, and the MOI of $10^{-4}$ was chosen for the subsequent experiments in this study.

\section{Analysis of calcium effect on adsorption rate}

Adsorption was the first step of phage infection of host bacteria and is often affected by the presence of divalent metal ions in the solution [20,21]. In the experiments, calcium ions were added to test their effects on adsorption efficacy. Phage AB1 and A. baumannii cells were mixed, free phage numbers, left in the solution, were detected at different time intervals. Statistical analysis showed significant differences existed between the two groups, and the results indicated calcium ions might stabilize phage adsorption process (Fig. 4).

\section{Latent time and phage burst size}

Single step growth experiment was performed to determine the latent time and phage burst size of phage AB1. As shown in Fig. 5, a triphasic curve, including the latent phase, rise phase, and plateau phase, was obtained. Using these data, the latent time was determined to be about 18 minutes, and the burst size of phage AB1 was $409 \mathrm{PFU} /$ infected cell.

\section{$\mathrm{pH}$ and thermal stability tests}

Optimal $\mathrm{pH}$ was determined by testing the stability of phage AB1 under different $\mathrm{pHs}$. Almost no reduction of infectious phage $A B 1$ was observed after one hour incubation at $\mathrm{pH} 6.0$, while different reduction percentages
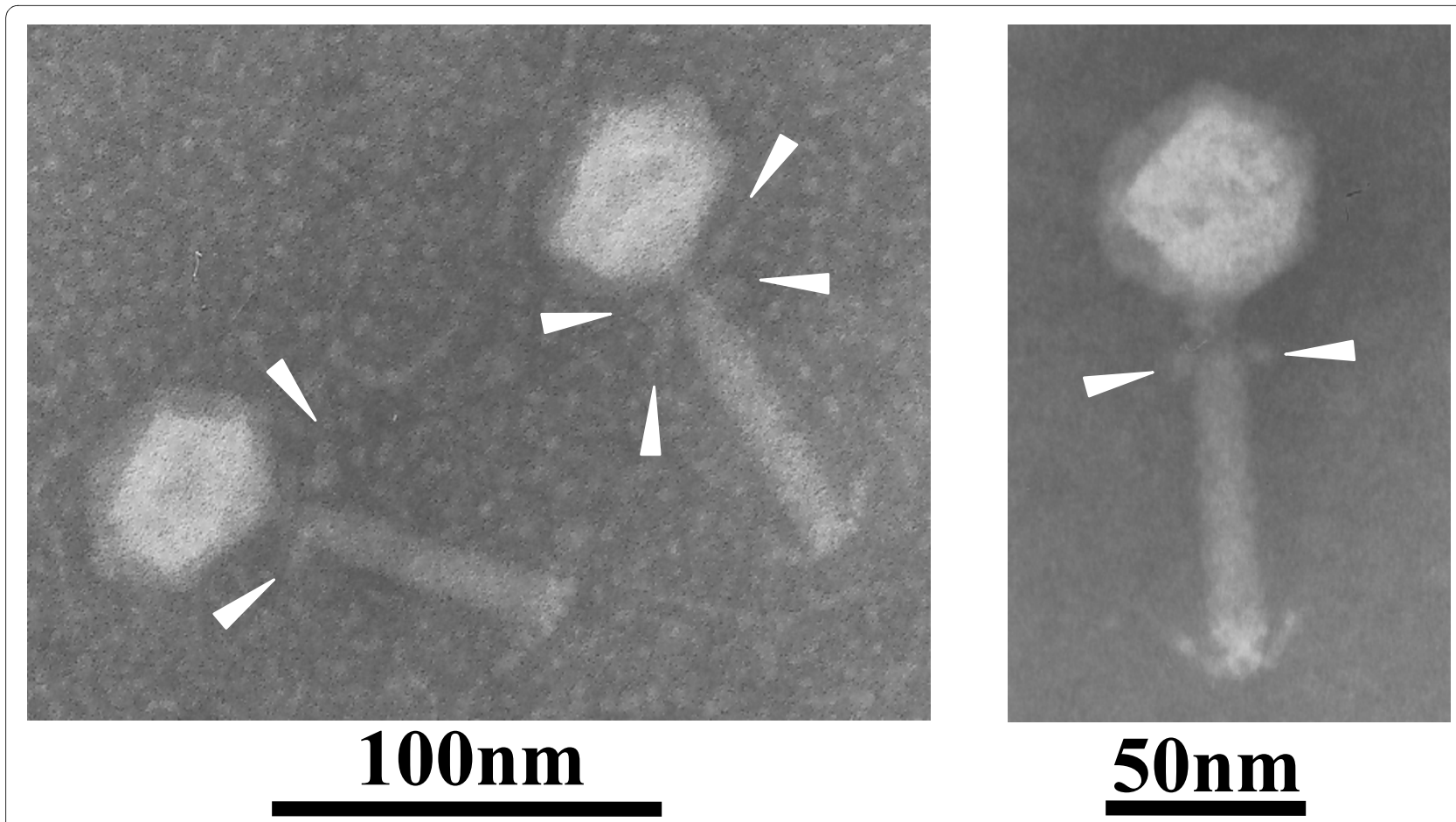

Figure 2 Transmission electron micrograph of phage particles. Virions were negatively stained with potassium phosphotungstate. The bar represents a length of $100 \mathrm{~nm}$ or $50 \mathrm{~nm}$. Blank arrows indicate collar or whisker structure of phage AB1. 


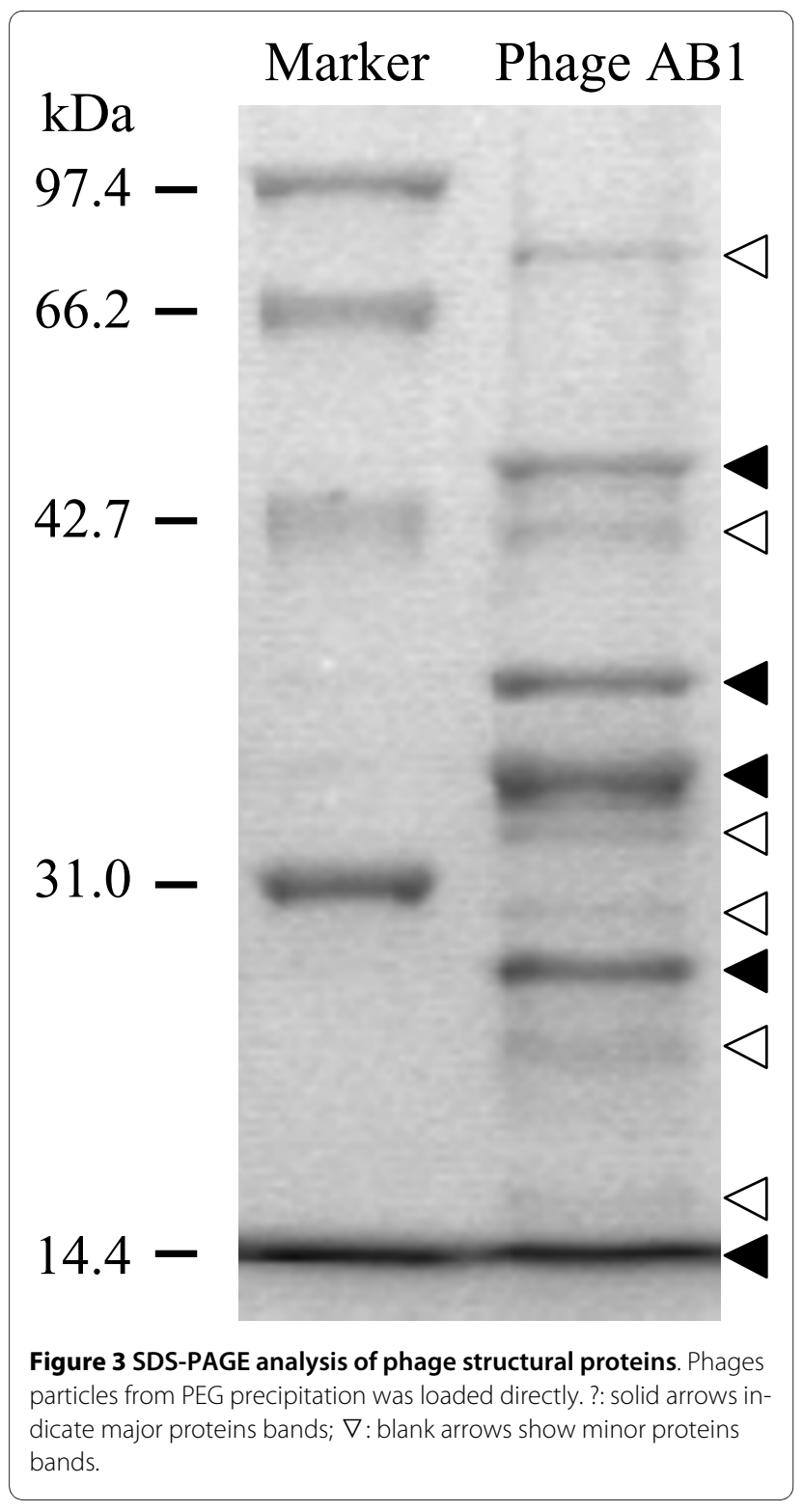

were obtained at other pHs, only $42.9 \%$ recovery of infectious phage $\mathrm{AB} 1$ at $\mathrm{pH} 5.0$. These results suggested that extreme pHs might affect phage AB1 stability (Fig. 6).

Thermal stability test was carried out to analyze heat resistant capability of phage AB1 at pH6.0. The preliminary experiments showed that phage $\mathrm{AB} 1$ stock solution retained almost $100 \%$ infection activity after incubation at $37^{\circ} \mathrm{C}$ for one month (not shown), so higher temperatures of $50^{\circ} \mathrm{C}, 60^{\circ} \mathrm{C}, 70^{\circ} \mathrm{C}, 80^{\circ} \mathrm{C}$, and $90^{\circ} \mathrm{C}$ were chosen to test thermal stability of phage $\mathrm{AB} 1$ (Fig. 7). The results showed phage AB1 was extremely heat stable, $73.2 \%$ and $64.1 \%$ phages still remained alive after 60 minutes incubation at $50^{\circ} \mathrm{C}$ and $60^{\circ} \mathrm{C}$, respectively; only $0.52 \%$ phages were alive after 60 minutes incubation at $70^{\circ} \mathrm{C}$; while more than $99 \%$ phages lost their infection ability in 15 minutes at $80^{\circ} \mathrm{C}$, or 5 minutes at $90^{\circ} \mathrm{C}$.

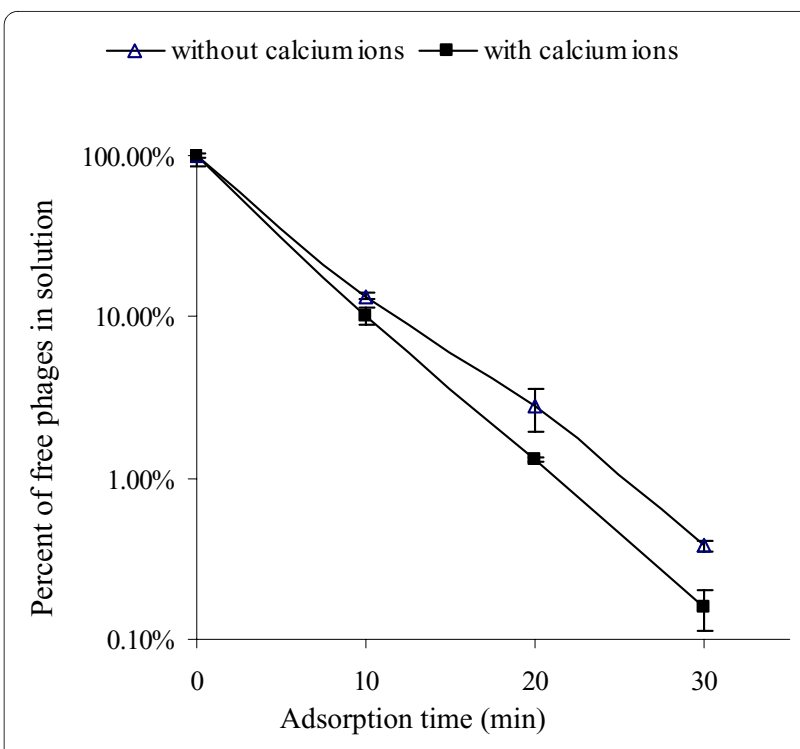

Figure 4 Adsorption rate test. At different time intervals, samples were taken from the supernatants to measure free phage particles. Divalent metal ions effect on adsorption rate was analyzed by adding 10 $\mathrm{mM} \mathrm{CaCl}$ to the mixture of phage $A B 1$ and $A$. baumannii cells.

\section{Host range}

The susceptibility to phage AB1 was also investigated with four other clinical strains of $A$. baumannii, one clinical strain of Stenotrophomonas maltophilia, and other lab bacteria strains such as Pseudomonas aeruginosa PAK and PAO1. No strain tested was found susceptible to phage AB1. The results indicated phage AB1 had a narrow host range, consistent with the previous discoveries [18]. Phages specifically targeting Acinetobacter spp. have narrow host ranges, usually one host one phage, and it's probably due to the existence of abundant surface bacterial antigens on this bacterium. These antigens are sufficient for different phage recognition [22].

\section{The susceptibility test}

Recently, most clinical isolates of $A$. baunannii were found to be resistant to many antibiotics still in use, making difficult the choice of an adequate antibiotic for the treatment of $A$. baunannii infections [1-3]. In our study, in vitro susceptibility tests of the 5 clinical strains were carried out (table 1). Among the 15 antibiotics tested, all strains were resistant to amoxicillin plus clavulanic acid, ampicillin, cefoxitin, cephalothin, and nitrofurantoin. Strain KD312 was only susceptible to 5 antibiotics, resistant to 10 others including imipenem. Strain KD311, the host of phage AB1, was susceptible to only 6 antibiotics including imipenem but resistant to gentamicin, differing from all other clinical isolates. All these data was coincident with the prevalence of multi-drug resistant $A$. baunannii infections throughout the world, indicating urgent statue of new drugs discovery. 


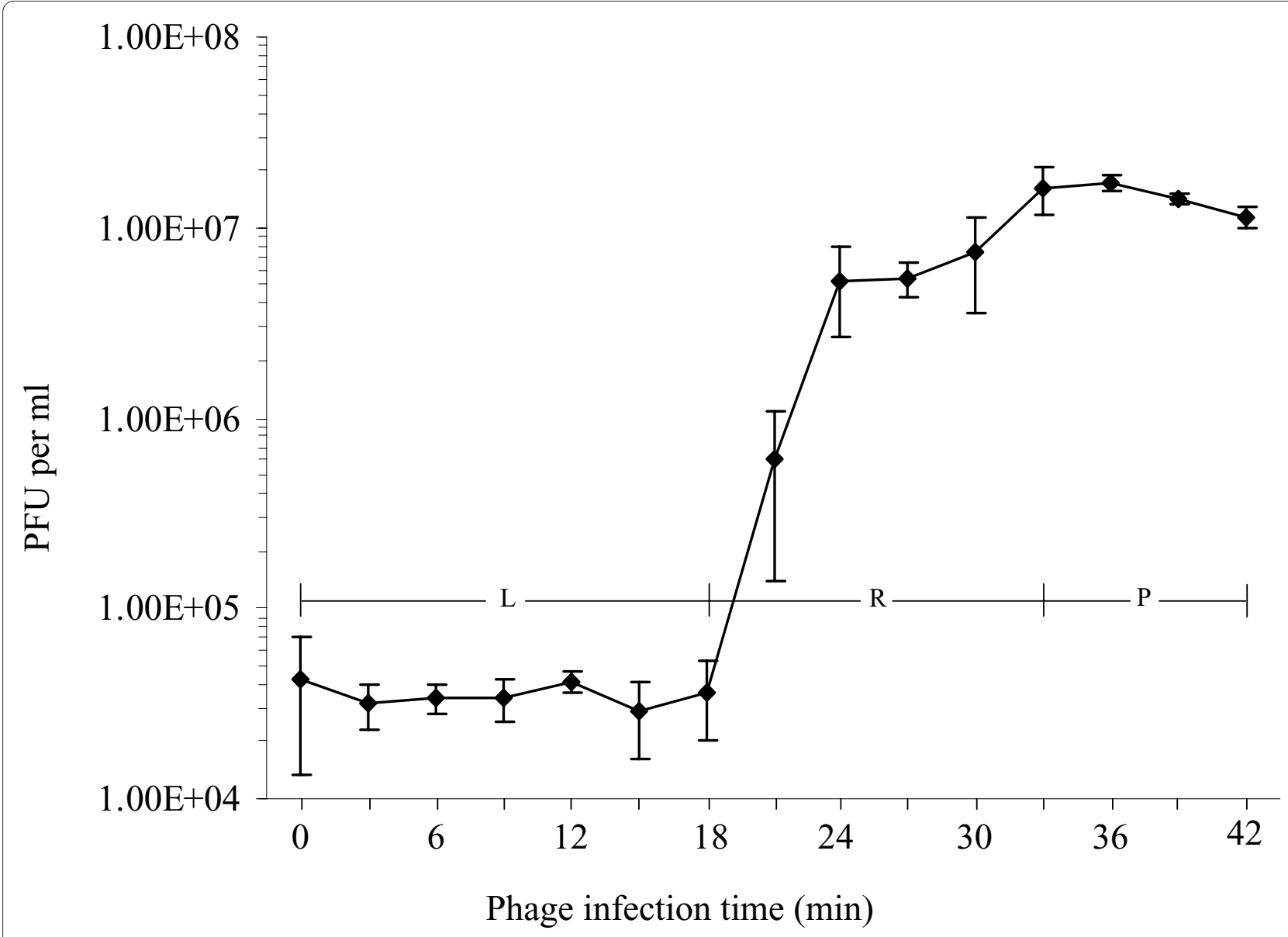

Figure 5 One step growth experiment. Latent time and burst size of phage AB1 were inferred from the curve with a triphasic pattern. L: latent phase; R: rise phase; P: plateau phase.

\section{Discussion}

Most classified Acinetobacter phages are tailed viruses with double stranded DNA genomes. They are classified into three families of the order of Caudovirales, including Myoviridae, Podoviridae, and Siphoviridae [18,23]. One exception is phage AP205 which is a ssRNA virus propagating in Acinetobacter species [19]. It belongs to Leviviridae family and tentatively classified into Levivius genus. In this study, phage AB1 had an icosahedral head with a non-contractile tail, and its genome was a molecule of double stranded DNA, so it was tentatively classified as a member of Siphoviridae family. Moreover, collar or whisker structures were also observed in the phage AB1 (Fig. 2). Similar complexes have been found in Escherichia coli phage T4 $[24,25]$ and lactic acid bacteria phages [26]. These structures are involved in phage assembly, possible regulation functions, sensing environmental conditions, and holding long tail fibers in a retracted conformation [25-30].

Thermal resistant phages were usually isolated from extreme thermal habits [31,32], but they could also be found in other environments. Recently, thermal resistant phages have been isolated and characterized from various dairy products $[33,34]$. Our experiment results showed that phage AB1 was quite heat resistant, $0.03 \%$ phages $\left(1.23 \times 10^{7} \mathrm{PFU} / \mathrm{ml}\right)$ were still infectious even after $15 \mathrm{~min}$ incubation at $90^{\circ} \mathrm{C}$ (Fig. 7). In the preliminary experiments, phage amplification lysate $\left(10^{10}-10^{11} \mathrm{PFU} / \mathrm{ml}\right)$ was heated directly at $100^{\circ} \mathrm{C}$ for stability test. After 5 minutes boiling, the alive phage concentration was still about $10^{5}$ $10^{6} \mathrm{PFU} / \mathrm{ml}$ (data not shown). Previous studies showed that media components of phage solution could affect the thermal stability of phage [35]. For phage AB1, the lysate supernatant of phage amplification was used directly in thermal stability tests without any additional substance added to LB medium. To demonstrate the mechanism of its notable thermal resistance, more experiments need to be done.

Nowadays, phage therapy has regained much attention due to the emergence of drug resistant pathogens and the dearth of new antibiotics in pipeline. In this study, phage $\mathrm{AB} 1$ specific to A. baumannii was isolated and character- 


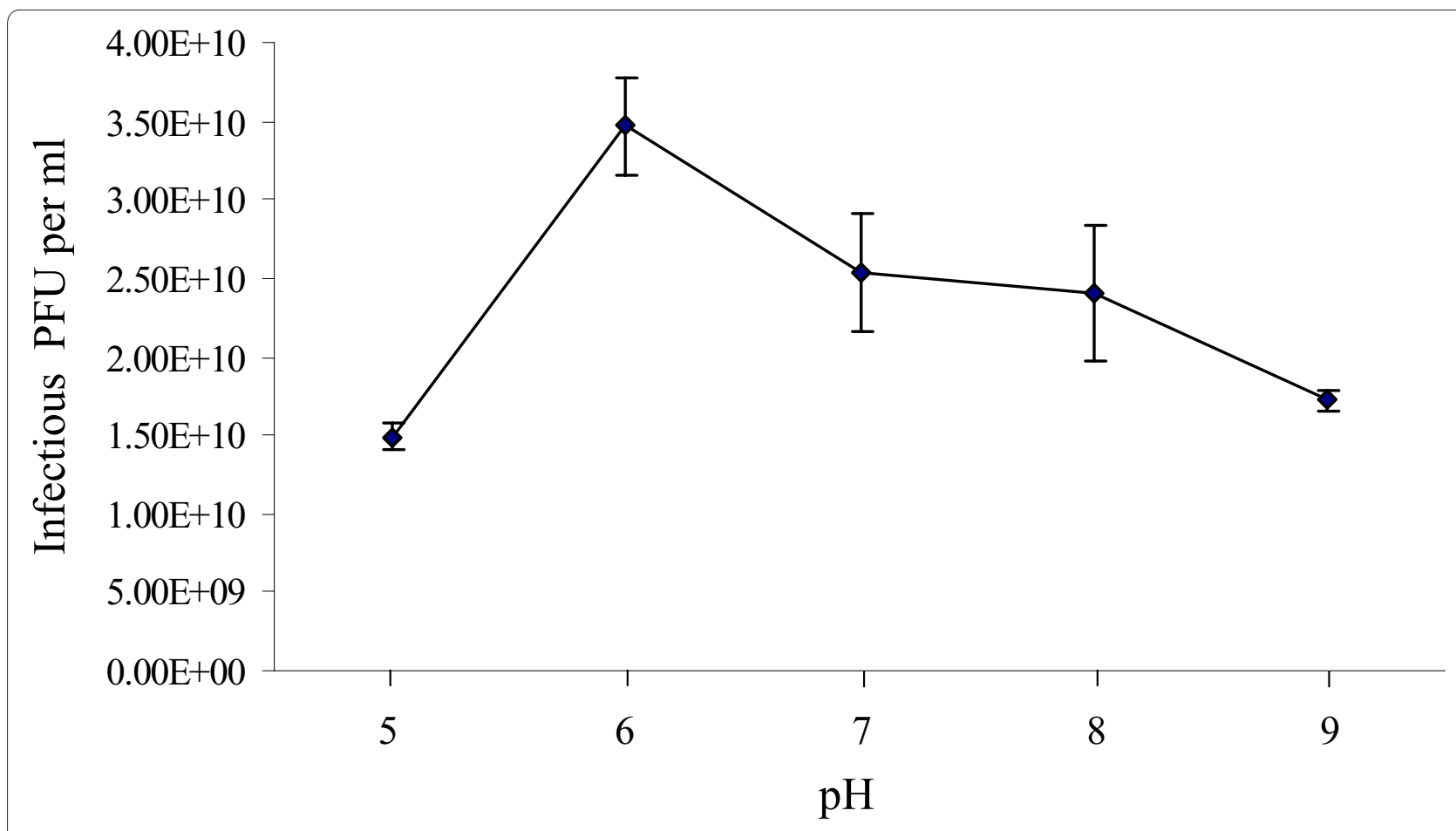

Figure $6 \mathrm{pH}$ stability test of phage AB1. Phage was incubated under different $\mathrm{pH}$ values for one hour before determining the number of infectious phage particles.

ized. The virus had some outstanding aspects including rapid growth nature, high $\mathrm{pH}$ stability, and high thermal resistance. All these characters made this phage very promised for possible applications in eradication of $A$. baumannii contaminations and or treatment of $A$. baumannii infections. However, there was a great diversity of surface antigens existed among the isolated clinical $A$. baumannii strains [22,36,37] and individual phage like AB1 with narrow host range was not suitable to be used directly [38]. In the future, more phages need to be isolated for preparations of cocktails which might be the best choice for phage applications.

\section{Conclusions}

Characterization of phage $\mathrm{AB} 1$ showed that it was very efficient in lysing $A$. baunannii, combined with its outstanding thermal stability, it may be a good candidate to be used as an alternative nontoxic green sanitizer. However, host range tests showed phage $\mathrm{AB} 1$ did not infect other A. baunannii clinical strains included in this study, suggesting that more virulent bacteriophages specific to different $A$. baunannii strains need to be screened and collected in future. A pool of lytic phages might be more useful against $A$. baunannii strains for possible phage applications.

\section{Materials and methods}

\section{Bacterial strains}

This study included a clinical strain of Stenotrophomonas maltophilia KD335 and 5 clinical strains of Acinetobacter calcoaceticus-baumannii complex, KD311, KD312, KD331, KD332, and KD334. All of them were isolated from hospitalized patients at Tianjin Children's Hospital, Tianjin, P. R. China. Also, other bacteria strains were used in phage host range test, including Pseudomonas aeruginosa PAK and PAO1 lab strains.

\section{Identification of bacterial strains by sequencing the $16 \mathrm{~s}$ rRNA gene}

Clinical strains were confirmed by sequencing the $16 \mathrm{~s}$ rRNA gene. Supernatant from boiled bacterial cells suspended in distilled water was used directly as PCR templates. Universal primers, 27f (5' AGA GTT TGA TCC TGG CTC AG 3') and 1492r (5' GGT TAC CTT GTT ACG ACT T 3'), were adopted to amplify the 16s rRNA genes [39]. Purified PCR products were sequenced directly with primers. Sequences of 16 s rRNA genes were deposited in GenBank under accession numbers $\underline{\text { FJ871007 (KD311), FJ871004 (KD312), } \text { FJ871006 }}$ (KD331), FJ871002 (KD332), FJ871003 (KD334), and FJ871005 (KD335). 


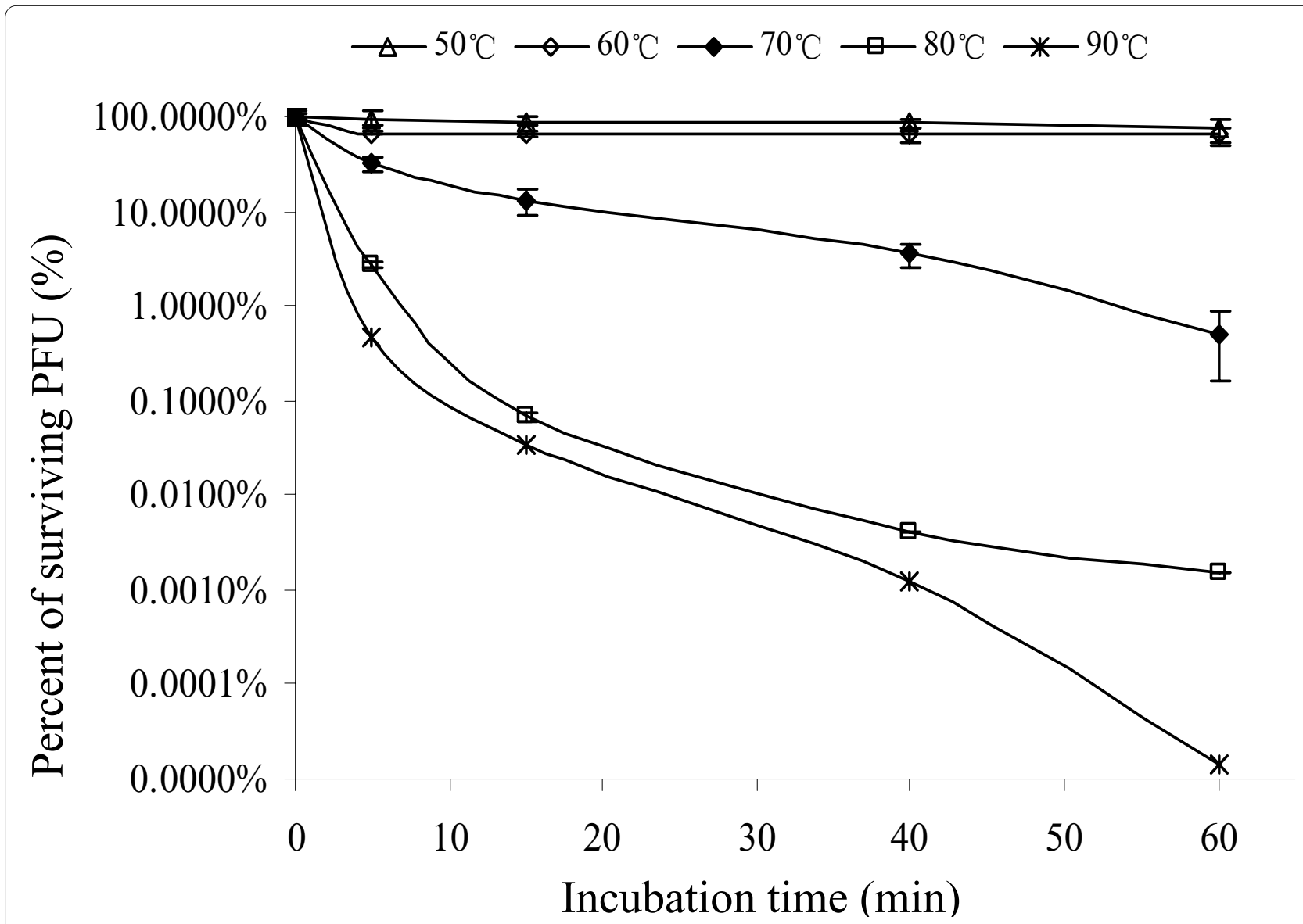

Figure 7 Thermal stability tests of phage AB1. Samples were taken at different time intervals to titer the surviving particles and calculate the percentage of infectious phages.

\section{Phage enrichment and isolation}

Luria-Bertani (LB) broth was used for liquid cultures, and $2 \%$ solid agar medium or $0.6 \%$ semi-solid agar medium were used for bacteria plating and phage plaque-forming assays, respectively. All incubations were carried out at $35^{\circ} \mathrm{C}$. Briefly, identified $A$. baumannii clinical strains were used as indicators for enriching and isolating virulent bacteriophages from marine sediment samples. In brief, marine sediment samples were taken from the coastal seashore $\left(38^{\circ} 59^{\prime} \mathrm{N}, 117^{\circ} 42^{\prime} \mathrm{E}\right)$ of China Bohai inner sea. Weighed 5 grams of samples and resuspended in 30 ml LB, $300 \mu \mathrm{l}$ overnight culture of $A$. baumannii was added to the mixture, incubated at $35^{\circ} \mathrm{C}$ for 6 hours with shaking to enrich $A$. baumannii-specific bacteriophages. At the end of incubation, drops of chloroform were added to the culture and the flask was left there for 15 minutes without shaking. The culture was filtrated with Whatman filter paper to remove soil particles, and the filtrate was spun down at $11,000 \mathrm{~g}$ for 5 minutes to remove bacterial cells and debris. Polyethylene glycol 6000 (PEG 6000) and sodium chloride was added to the supernatant to the final concentrations of $10 \%$ and $1 \mathrm{M}$, respectively. The solution was incubated at $4^{\circ} \mathrm{C}$ overnight, spun at $11,000 \mathrm{~g}$ for 20 minutes. The pellet was dissolved in $1 \mathrm{ml}$ phosphatebuffered saline, the resulting solution was subjected to $0.45 \mu \mathrm{m}$ filter to remove the residual bacterial cells. The enriched phage solution was mixed with exponential growth culture of $A$. baumannii and plated in semi-solid agar medium after 15 minutes adsorption. Plaques formed on the plates after 4 hours incubation at $35^{\circ} \mathrm{C}$. Single plaque was picked out for subsequent phage purification and amplification [40,41].

\section{Analysis of phage genomic DNA and total phage structural proteins}

Molecular manipulations were carried out as previously described [42]. Phage AB1 particles were amplified and purified according to the phage isolation procedures and bacteriophage DNA was isolated by the method described previously $[40,41,43]$. Restriction endonucleases were used to digest phage genomic DNA, and the genome size was estimated by compilation of DNA fragment sizes resulting from restriction enzymes digestion profiles. DNA molecular standards were from Tiangen 
Table 1: In vitro susceptibility tests of 5 clinical A. baumannii strains

\begin{tabular}{|c|c|c|c|c|c|c|c|c|c|c|}
\hline \multirow{3}{*}{$\begin{array}{c}\text { Antibiotics } \\
\text { Amoxicillin/CA } \\
\end{array}$} & \multicolumn{10}{|c|}{ MIC $(\mu \mathrm{g} / \mathrm{ml}) \mathrm{b}$} \\
\hline & \multicolumn{2}{|c|}{ KD311 } & \multicolumn{2}{|c|}{ KD312 } & \multicolumn{2}{|c|}{ KD331 } & \multicolumn{2}{|c|}{ KD332 } & \multicolumn{2}{|c|}{ KD334 } \\
\hline & $\cdot 32$ & $\mathrm{R}$ & $\cdot 32$ & $\mathrm{R}$ & $\cdot 32$ & $\mathrm{R}$ & $\cdot 32$ & $\mathrm{R}$ & $\cdot 32$ & $\mathrm{R}$ \\
\hline Ampicillin & $\cdot 32$ & $\mathrm{R}$ & $\cdot 32$ & $\mathrm{R}$ & $\cdot 32$ & $\mathrm{R}$ & $\cdot 32$ & $\mathrm{R}$ & $\cdot 32$ & $\mathrm{R}$ \\
\hline Cefotaxime & 16 & I & $\cdot 64$ & $\mathrm{R}$ & 16 & I & 16 & I & 16 & I \\
\hline Cefoxitin & $\cdot 32$ & $\mathrm{R}$ & $\cdot 32$ & $\mathrm{R}$ & $\cdot 32$ & $\mathrm{R}$ & $\cdot 32$ & $\mathrm{R}$ & $\cdot 32$ & $\mathrm{R}$ \\
\hline Ceftazidime & $\cdot 8$ & $\mathrm{~S}$ & $\cdot 32$ & $\mathrm{R}$ & $\cdot 8$ & $\mathrm{~S}$ & $\cdot 32$ & $\mathrm{R}$ & 16 & I \\
\hline Cephalothin & $\cdot 32$ & $\mathrm{R}$ & $\cdot 32$ & $\mathrm{R}$ & $\cdot 32$ & $\mathrm{R}$ & $\cdot 32$ & $\mathrm{R}$ & $\cdot 32$ & $\mathrm{R}$ \\
\hline Gentamicin & $\cdot 16$ & $\mathrm{R}$ & 1 & $\mathrm{~S}$ & $\cdot 0.5$ & $\mathrm{~S}$ & 2 & $\mathrm{~S}$ & $\cdot 0.5$ & S \\
\hline Imipenem & $\cdot 4$ & $\mathrm{~S}$ & $\cdot 6$ & $\mathrm{R}$ & $\cdot 4$ & $\mathrm{~S}$ & $\cdot 4$ & $\mathrm{~S}$ & $\cdot 4$ & S \\
\hline Nalidixic Acid & $\cdot 16$ & $\mathrm{~S}$ & $\cdot 16$ & $\mathrm{~S}$ & $\cdot 16$ & $\mathrm{~S}$ & $\cdot 16$ & $\mathrm{~S}$ & $\cdot 16$ & S \\
\hline Netilmicin & $\cdot 4$ & $\mathrm{~S}$ & 16 & I & $\cdot 4$ & $\mathrm{~S}$ & $\cdot 4$ & $\mathrm{~S}$ & $\cdot 4$ & S \\
\hline Nitrofurantoin & $\cdot 128$ & $\mathrm{R}$ & $\cdot 128$ & $\mathrm{R}$ & $\cdot 128$ & $\mathrm{R}$ & $\cdot 128$ & $\mathrm{R}$ & $\cdot 128$ & $\mathrm{R}$ \\
\hline Pefloxacin & $\cdot 1$ & $\mathrm{~S}$ & $\cdot 1$ & $\mathrm{~S}$ & $\cdot 1$ & $\mathrm{~S}$ & $\cdot 1$ & $\mathrm{~S}$ & $\cdot 1$ & $\mathrm{~S}$ \\
\hline Ticarcillin & 128 & $\mathrm{R}$ & 128 & $\mathrm{R}$ & $\cdot 16$ & $\mathrm{~S}$ & $\cdot 256$ & $\mathrm{R}$ & $\cdot 16$ & S \\
\hline Tobramycin & $\cdot 0.5$ & $\mathrm{~S}$ & 1 & $\mathrm{~S}$ & $\cdot 0.5$ & $\mathrm{~s}$ & $\cdot 0.5$ & $\mathrm{~S}$ & $\cdot 0.5$ & $\mathrm{~S}$ \\
\hline Trimethoprim/Sulfa & $\cdot 320$ & $\mathrm{R}$ & 40 & $\mathrm{~S}$ & $\cdot 10$ & $\mathrm{~S}$ & 80 & $\mathrm{R}$ & $\cdot 10$ & $\mathrm{~s}$ \\
\hline
\end{tabular}

a. clavulanic acid at a fixed concentration of $2 \mu \mathrm{g} / \mathrm{ml}$.

b. R: resistant; S: susceptible; I: intermediate.

Biotech (Beijing) Co., Ltd. To prepare protein sample for SDS-PAGE analysis, purified phage AB1 solution was subjected to Amicon-100 filters, and the phage particles were further washed three times with $0.1 \mathrm{M}$ ammonium acetate solution ( $\mathrm{pH} 7.0)$ to remove possibly existed residual bacterial proteins. Purified phage particles were subjected to SDS-PAGE directly, and the gel stained with Coomassie Blue G-250.

\section{Morphology study by transmission electron microscope}

Phage AB1 solution was filtrated with Amicon-100 filter to remove soluble biological macromolecule fragments of host bacteria. After washing three times with $0.1 \mathrm{M}$ ammonium acetate solution ( $\mathrm{pH} 7.0)$, the retained phage solution was used directly for negative staining as described previously [44]. Photographs were taken with a JEOL1011 transmission electron microscope operating at $100 \mathrm{kV}$.

\section{Determination of multiplicity of infection (MOI)}

Serial dilutions of bacteriophage stock solution were mixed with the same amount of $A$. baumannii cells. After 15 minutes adsorption, free bacteriophages were removed by centrifugation at 5,000 g for $10 \mathrm{~min}$, pellets were resuspended with LB medium, and samples were taken for bacteriophage titer analysis after 4 hours incubation at $35^{\circ} \mathrm{C}$.

\section{Adsorption rate, latent period, and phage burst size}

As described previously [20,21], $10 \mathrm{mM} \mathrm{CaCl}_{2}$ was added to the infected culture to measure divalent metal ions effects on adsorption rate of phage $A B 1$, samples were taken at different time intervals to analyze the free phage particles in the solutions with and without addition of calcium ions. One-step growth experiment was carried out according to the previous descriptions $[45,46]$ to determine the latent period and phage burst size. In brief, $50 \mathrm{ml}$ bacterial cells of $A$. baumannii KD311 were incubated to mid-exponential-phase $\left(\mathrm{OD}_{600}=0.4-0.6\right)$ and harvested by centrifugation. The pellet was resuspended in $0.5 \mathrm{ml}$ fresh LB medium and mixed with $0.5 \mathrm{ml}$ phage AB1 solution $\left(1 \times 10^{8} \mathrm{PFU} / \mathrm{ml}\right)$. Phage AB1 was allowed to adsorb for $1 \mathrm{~min}$ and the mixture was subjected to centrifugation immediately at $13,000 \mathrm{rpm}$ for 30 seconds to remove free phage particles. The pellet was resuspended in $100 \mathrm{ml}$ fresh LB medium and the culture was continuously incubated at $35^{\circ} \mathrm{C}$. Samples were taken at $3 \mathrm{~min}$ intervals and phage titre was determined by the doublelayer-agar plate method. The results were analyzed and the constant phage titer, which represented the number of infective centres, along the latent stage was deduced. The burst size of phage AB1 was calculated by dividing the phage titers at plateau phase by the number of infective centres. 


\section{$\mathrm{pH}$ stability and thermal stability test}

$\mathrm{pH}$ stability and thermal stability tests were carried out as previously described $[47,48]$. Briefly, certain amount of phage particles were treated under specified conditions. Samples were taken at different time intervals and supernatants from centrifugation were used directly in the assays. Initial phage concentration was about $3.5 \times 10^{10}$ $\mathrm{PFU} / \mathrm{ml}$ in LB medium.

\section{Host range determination}

$10^{8}$ bacterial cells were mixed with melted $0.6 \%$ agar $\left(50^{\circ} \mathrm{C}\right)$ and this mixture was poured on a $2 \%$ solid agar to make double layer agar plates. After solidification, we spotted the isolated bacteriophage stock solution on each plate with different bacterium strain and observed whether lysis plaques emerged.

\section{The susceptibility test}

BioMerieux Vitek 32 system (BioMerieux, Inc., USA) was used in clinical samples diagnosis for bacterial identifications and antibiotics susceptibility tests.

\section{Authors' contributions}

HY designed the experiments and wrote this manuscript; LL performed all phage related experiments; SL analyzed the clinical bacteria strains; HY and SJ supervised the work. The final work was read and accepted by all co-authors.

\section{Acknowledgements}

The authors thank Dr Jingfu Huang (Tianjin Children Hospital, Tianjin, China) for generously providing the bacterial strains used in this study. This study was supported by a grant (No. 08JC26600) from Tianjin Natural Science Foundation, Tianjin, PR China.

\section{Author Details}

1 Key Laboratory of Industrial Microbiology, Ministry of Education, PO Box 08, Tianjin University of Science \& Technology, TEDA, Tianjin 300457, PR China and 2Tianjin Children's Hospital, 225 Machang Road, Tianjin 300074, PR China

Received: 15 May 2009 Accepted: 29 April 2010

Published: 29 April 2010

\section{References}

1. Perez F, Hujer AM, Hujer KM, Decker BK, Rather PN, Bonomo RA: Global challenge of multidrug-resistant Acinetobacter baumannii. Antimicrob Agents Chemother 2007, 51(10):3471-3484.

2. Peleg AY, Seifert H, Paterson DL: Acinetobacter baumannii: emergence of a successful pathogen. Clin Microbiol Rev 2008, 21(3):538-582.

3. Dijkshoorn L, Nemec A, Seifert H: An increasing threat in hospitals: multidrug-resistant Acinetobacter baumannii. Nat Rev Microbio/ 2007 5(12):939-951.

4. Navon-Venezia S, Ben-Ami R, Carmeli Y: Update on Pseudomonas aeruginosa and Acinetobacter baumannii infections in the healthcare setting. Curr Opin Infect Dis 2005, 18(4):306-313.

5. Barbolla RE, Centron D, Maimone S, Rospide F, Salgueira C, Altclas J, Catalano M: Molecular epidemiology of Acinetobacter baumannii spread in an adult intensive care unit under an endemic setting. Am J Infect Control 2008, 36(6):444-452.

6. Mastoraki A, Douka E, Kriaras I, Stravopodis G, Saroglou G, Geroulanos S: Preventing strategy of multidrug-resistant Acinetobacter baumanii susceptible only to colistin in cardiac surgical intensive care units. Eur J Cardiothorac Surg 2008, 33(6):1086-1090.

7. Summers WC: Bacteriophage therapy. Annu Rev Microbio/ 2001, 55:437-451

8. Sulakvelidze A, Alavidze Z, Morris JG Jr: Bacteriophage therapy. Antimicrob Agents Chemother 2001, 45(3):649-659.
9. Coates $A R$, Hu Y: Novel approaches to developing new antibiotics for bacterial infections. Br J Pharmacol 2007, 152(8):1147-1154.

10. Poole K: Overcoming multidrug resistance in gram-negative bacteria. Curr Opin Investig Drugs 2003, 4(2):128-139.

11. Merril CR, Scholl D, Adhya SL: The prospect for bacteriophage therapy in Western medicine. Nat Rev Drug Discov 2003, 2(6):489-497.

12. Bren $L$ : Bacteria-eating virus approved as food additive. FDA Consum 2007, 41(1):20-22

13. Thiel K: Old dogma, new tricks--21st Century phage therapy. Nat Biotechnol 2004, 22(1):31-36

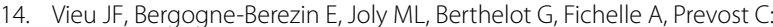
Epidemiology of Acinetobacter calcoaceticus. Nouv Presse Med 1980, 9(46):3551-3552.

15. Bouvet PJ, Jeanjean S, Vieu JF, Dijkshoorn L: Species, biotype, and bacteriophage type determinations compared with cell envelope protein profiles for typing Acinetobacter strains. J Clin Microbiol 1990, 28(2):170-176

16. Soothill JS: Treatment of experimental infections of mice with bacteriophages. J Med Microbiol 1992, 37(4):258-261

17. Barrow PA, Soothill JS: Bacteriophage therapy and prophylaxis: rediscovery and renewed assessment of potential. Trends Microbiol 1997, 5(7):268-271.

18. Ackermann HW, Brochu G, Emadi Konjin HP: Classification of Acinetobacter phages. Arch Virol 1994, 135(3-4):345-354.

19. Klovins J, Overbeek GP, Worm SH van den, Ackermann HW, van Duin J: Nucleotide sequence of a ssRNA phage from Acinetobacter: kinship to coliphages. J Gen Virol 2002, 83(Pt 6):1523-1533.

20. Shafia F, Thompson TL: Calcium Ion Requirement for Proliferation of Bacteriophage Phi Mu-4. J Bacteriol 1964, 88:293-296.

21. Suarez V, Moineau S, Reinheimer J, Quiberoni A: Argentinean Lactococcus lactis bacteriophages: genetic characterization and adsorption studies. J Appl Microbiol 2008, 104(2):371-379.

22. Marcus BB, Samuels SB, Pittman B, Cherry WB: A serologic study of Herellea vaginicola and its identification by immunofluorescent staining. Am J Clin Pathol 1969, 52(3):309-319.

23. Büchen-Osmond C: ICTVdB Management. 02. Caudovirales. In: ICTVdB The Universal Virus Database, version 4. New York, USA: Columbia University; 2006

24. Letarov A, Manival X, Desplats C, Krisch HM: gpwac of the T4-type bacteriophages: structure, function, and evolution of a segmented coiled-coil protein that controls viral infectivity. J Bacteriol 2005 187(3):1055-1066.

25. Golitsyna NL, Selivanov NA, Rustembekov OS, Mesianzhinov W: [Isolation of biologically active halves of the long tail fibers and whiskers of bacteriophage T4]. Nauchnye Doki Vyss Shkoly Biol Nauki 1983:27-32.

26. Vegge CS, Neve H, Brondsted L, Heller KJ, Vogensen FK: Analysis of the collar-whisker structure of temperate lactococcal bacteriophage TP901-1. Appl Environ Microbio/ 2006, 72(10):6815-6818.

27. Wood WB, Conley MP: Attachment of tail fibers in bacteriophage T4 assembly: role of the phage whiskers. J Mol Biol 1979, 127(1):15-29.

28. Vegge CS, Brondsted L, Neve H, Mc Grath S, van Sinderen D, Vogensen FK: Structural characterization and assembly of the distal tail structure of the temperate lactococcal bacteriophage TP901-1. J Bacterio/ 2005 , 187(12):4187-4197.

29. Conley MP, Wood WB: Bacteriophage T4 whiskers: a rudimentary environment-sensing device. Proc Natl Acad Sci USA 1975, 72(9):3701-3705.

30. Efimov VP, Nepluev IV, Sobolev BN, Zurabishvili TG, Schulthess T, Lustig A Engel J, Haener M, Aebi U, Venyaminov S, et al.: Fibritin encoded by bacteriophage T4 gene wac has a parallel triple-stranded alpha-helical coiled-coil structure. J Mol Biol 1994, 242(4):470-486.

31. Rice G, Stedman K, Snyder J, Wiedenheft B, Willits D, Brumfield S, McDermott T, Young MJ: Viruses from extreme thermal environments. Proc Natl Acad Sci USA 2001, 98(23):13341-13345.

32. Arnold HP, Zillig W, Ziese U, Holz I, Crosby M, Utterback T, Weidmann JF, Kristjanson JK, Klenk HP, Nelson KE, et al:: A novel lipothrixvirus, SIFV, of the extremely thermophilic crenarchaeon Sulfolobus. Virology 2000 267(2):252-266

33. Capra ML, Binetti AG, Mercanti DJ, Quiberoni A, Reinheimer JA: Diversity among Lactobacillus paracasei phages isolated from a probiotic dairy product plant. J App/Microbio/ 2009, 107(4):1350-1357. 
34. Atamera Z, Dietrichb J, Müller-Merbacha M, Neveb H, Hellerb KJ, Hinrichsa $\mathrm{J}$ : Screening for and characterization of Lactococcus lactis bacteriophages with high thermal resistance. International Dairy Journal 2009, 19(4):228-235.

35. Briggiler Marco M, De Antoni GL, Reinheimer JA, Quiberoni A: Thermal, chemical, and photocatalytic inactivation of Lactobacillus plantarum bacteriophages. J Food Prot 2009, 72(5):1012-1019.

36. Ko WC, Lee NY, Su SC, Dijkshoorn L, Vaneechoutte M, Wang LR, Yan JJ, Chang TC: Oligonucleotide array-based identification of species in the Acinetobacter calcoaceticus-A. baumannii complex in isolates from blood cultures and antimicrobial susceptibility testing of the isolates. $J$ Clin Microbio/ 2008, 46(6):2052-2059.

37. Pantophlet R, Severin JA, Nemec A, Brade L, Dijkshoorn L, Brade H: Identification of Acinetobacter isolates from species belonging to the Acinetobacter calcoaceticus-Acinetobacter baumannii complex with monoclonal antibodies specific for O Antigens of their lipopolysaccharides. Clin Diagn Lab Immunol 2002, 9(1):60-65.

38. Gorski A, Miedzybrodzki R, Borysowski J, Weber-Dabrowska B, Lobocka M, Fortuna W, Letkiewicz S, Zimecki M, Filby G: Bacteriophage therapy for the treatment of infections. Curr Opin Investig Drugs 2009, 10(8):766-774.

39. Gurtler V, Stanisich VA: New approaches to typing and identification of bacteria using the 16S-23S rDNA spacer region. Microbiology 1996, 142(Pt 1):3-16.

40. Stenholm AR, Dalsgaard I, Middelboe M: Isolation and characterization of bacteriophages infecting the fish pathogen Flavobacterium psychrophilum. Appl Environ Microbio/ 2008, 74(13):4070-4078.

41. Carey-Smith GV, Billington C, Cornelius AJ, Hudson JA, Heinemann JA: Isolation and characterization of bacteriophages infecting Salmonella spp. FEMS Microbiol Lett 2006, 258(2):182-186.

42. Sambrook J, Russell D: Molecular Cloning: A Laboratory Manual (Third Edition). 3rd edition. New York: Cold Spring Harbor Laboratory Press; 2001

43. O'Flaherty S, Coffey A, Edwards R, Meaney W, Fitzgerald GF, Ross RP: Genome of staphylococcal phage K: a new lineage of Myoviridae infecting gram-positive bacteria with a low $\mathrm{G}+\mathrm{C}$ content. J Bacterio/ 2004, 186(9):2862-2871.

44. Nugent KM, Cole RM: Characterization of group $\mathrm{H}$ streptococcal temperate bacteriophage phi 227. J Virol 1977, 21(3):1061-1073.

45. Adams MH: Bacteriophages. New York: Interscience; 1959.

46. Chow JJ, Batt CA, Sinskey AJ: Characterization of Lactobacillus bulgaricus Bacteriophage ch2. App/ Environ Microbiol 1988, 54(5):1138-1142.

47. Capra ML, Quiberoni A, Reinheimer J: Phages of Lactobacillus casei/ paracasei: response to environmental factors and interaction with collection and commercial strains. J App/ Microbiol 2006 100(2):334-342

48. Capra ML, Quiberoni A, Reinheimer JA: Thermal and chemical resistance of Lactobacillus casei and Lactobacillus paracasei bacteriophages. Lett Appl Microbiol 2004, 38(6):499-504

doi: 10.1186/1471-2180-10-131

Cite this article as: Yang et al., Isolation and Characterization of a Virulent Bacteriophage AB1 of Acinetobacter baumannii BMC Microbiology 2010, 10:131
Submit your next manuscript to BioMed Centra and take full advantage of:

- Convenient online submission

- Thorough peer review

- No space constraints or color figure charges

- Immediate publication on acceptance

- Inclusion in PubMed, CAS, Scopus and Google Scholar

- Research which is freely available for redistribution

Submit your manuscript at www.biomedcentral.com/submit
C Biomed Central 